\title{
Spontaneous subcapsular haematoma: a rare cause of acute kidney graft dysfunction
}

\author{
Sofia Cerqueira, ${ }^{1}$ Inês Dionísio Coelho, ${ }^{2}$ Fernando Macário, ${ }^{3}$ Arnaldo Figueiredo ${ }^{3,4}$
}

${ }^{1}$ Nephrology Department,

Centro Hospitalar Trás-os-

Montes e Alto Douro, Vila Real, Portugal

${ }^{2}$ Nephrology, Hospital Amato Lusitano, Castelo Branco,

Portugal

${ }^{3}$ Nephrology and Urology and Transplant Department, Centro Hospitalar e Universitario de Coimbra EPE, Coimbra, Coimbra, Portugal

${ }^{4}$ Urology and Transplant Department, Universidade de Coimbra Faculdade de Medicina, Coimbra, Coimbra, Portugal

Correspondence to Dr Sofia Cerqueira, ssacerqueira@gmail.com

Accepted 5 January 2019

\section{DESCRIPTION}

A 39-year-old patient who had kidney transplant presented at the emergency department with pain in his right flank that was ongoing for 15 days. It had started suddenly when he was driving his taxi, after a coughing effort. No haematuria and no history of trauma.

He had had a deceased donor kidney transplant 10 years before, put in his right flank. Histocompatibilities were: $1 \mathrm{DR}$ and $2 \mathrm{AB}, \mathrm{PRA}$ was $0 \%$. He had delayed thrombosis of his renal artery diagnosed intraoperatively and had thromboembolectomy immediately. He also had delayed graft function and maintained slight chronic graft dysfunction (sCr $221 \mu \mathrm{mol} / \mathrm{L}$ ). He was not on any blood thinners. His initial immunosuppression was ciclosporin, mycophenolate mophetil and prednisolone, but ciclosporin had been removed in 2008 by a previous attending nephrologist. He had never had a kidney biopsy.

He was haemodynamically stable and there was a palpable painful mass in his right flank. Ultrasonography showed a $15 \mathrm{~cm}$ suspicious solid mass in his kidney transplant. Suspicion was high for neoplasia. His blood film showed $\mathrm{sCr} 318 \mu \mathrm{mol} / \mathrm{L}$ and platelets $220000 / \mu \mathrm{L}$. Coagulation profile was unremarkable (PT 12.5s, INR 1.09). His evolution was with progressive kidney dysfunction and olygoanuria, so he started haemodialysis, without heparinisation, on day 2 of admission. He maintained need for haemodialysis support for 1 week. His baseline immunossupression

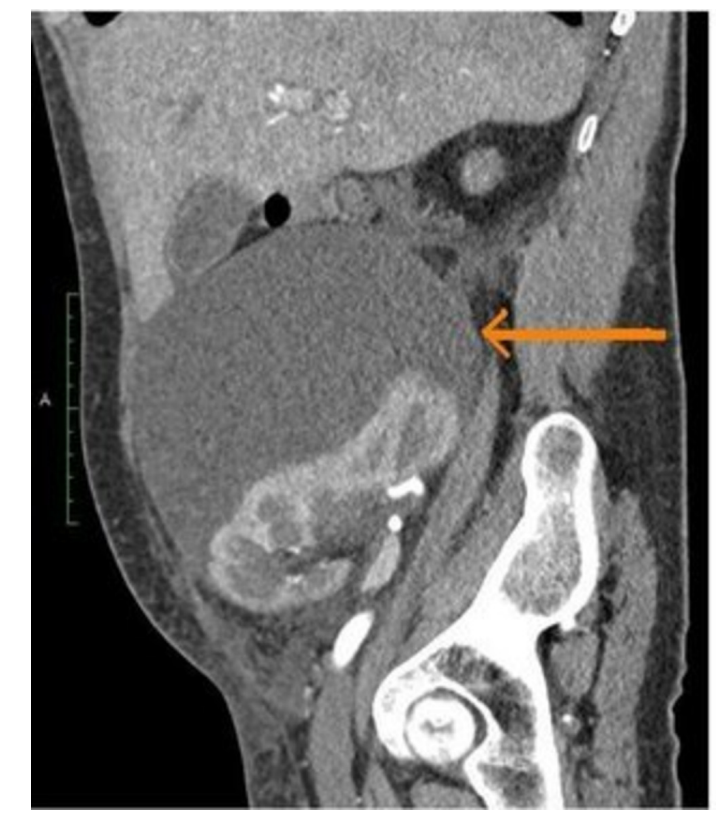

Figure 1 CT urogram shows a $16 \mathrm{~cm}$ solid mass surrounding the kidney allograft (orange arrow).

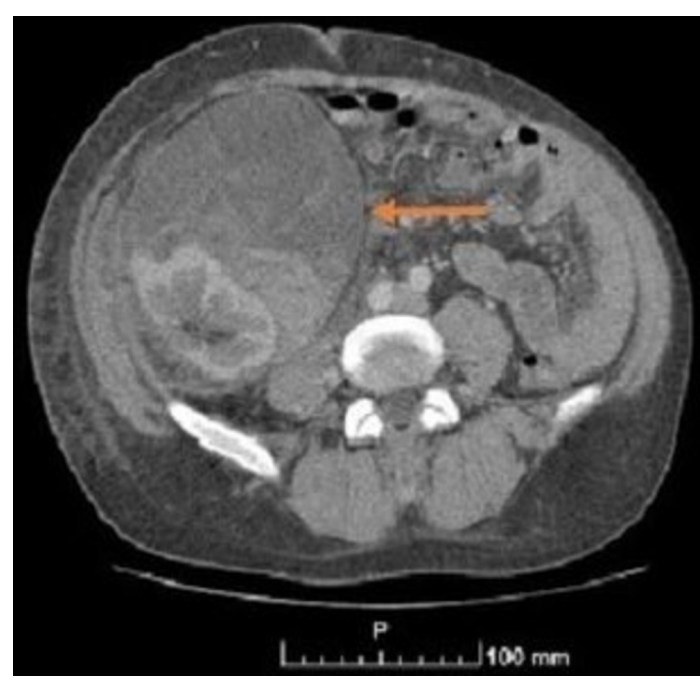

Figure 2 The image on CT urogram represents an haematoma with well-defined margins (orange arrow).

was kept. After 1 week, he recovered kidney function, so a kidney biopsy was not performed. His last serum Cr was $212 \mu \mathrm{mol} / \mathrm{L}$.

On angio-CT a $16 \mathrm{~cm}$ diameter haematoma was diagnosed, with no evidence of active haemorrhage (figures 1 and 2). As the haematoma was stable, the decision was not to perform surgical exploration. Instead, the indication was for bed rest, and a control CT showed regression of the dimensions of the haematoma (figure 3).

This is a surprising case, as suspicion was initially high for a neoplasia. As these patients are subjected to a

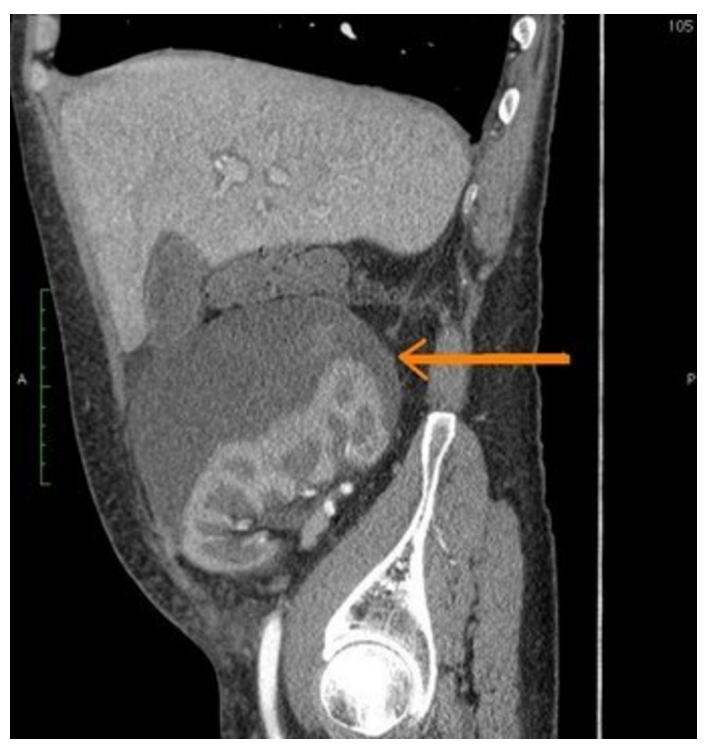

Figure 3 A control CT showed regression of the haematoma (orange arrow). 


\section{Learning points}

Most late complications postkidney transplant are due to either allograft failure or secondary effects of longterm immunosuppressive medication on the receptor (cardiovascular disease, infection, malignancy). ${ }^{1}$ However, we must keep our minds open to the hypothesis of other not-sofrequent causes of graft dysfunction.

- This is a rare complication in the late postkidney transplant period. This patient was not on any blood thinners and also was not taking any antiaggregant, he had no thrombocytopenia and still had a spontaneous subcapsular haemorrhage. As was noted, he only had a history of a spontaneous thrombus at the time of transplant.

- A thorough workup and expeditious imaging study are invaluable resources to help distinguish this entity from other more frequent causes of graft dysfunction. high degree of immunosuppression, they are more likely to develop atypical infections or tumours. The actual diagnosis turned out to be a rare complication in the late postkidney transplant period.

Acknowledgements The authors would like to thank Dr Catarina Romãozinho for her invaluable support on writing this report.

Contributors SC and IDC have planned, conceived and written the document. AF and FM have supervised and helped with the interpretation of data.

Funding The authors have not declared a specific grant for this research from any funding agency in the public, commercial or not-for-profit sectors.

Competing interests None declared.

Patient consent for publication Obtained.

Provenance and peer review Not commissioned; externally peer reviewed.

\section{REFERENCE}

1 Danovitch GM. Handbook of Kidney Transplantation (sixth edition): Wolters Kluwer, 2017.

Copyright 2018 BMJ Publishing Group. All rights reserved. For permission to reuse any of this content visit https://www.bmj.com/company/products-services/rights-and-licensing/permissions/

BMJ Case Report Fellows may re-use this article for personal use and teaching without any further permission.

Become a Fellow of BMJ Case Reports today and you can:

- Submit as many cases as you like

- Enjoy fast sympathetic peer review and rapid publication of accepted articles

- Access all the published articles

Re-use any of the published material for personal use and teaching without further permission

For information on Institutional Fellowships contact consortiasales@bmjgroup.com

Visit casereports.bmj.com for more articles like this and to become a Fellow 